\title{
Formed Core Sampler Hydraulic Conductivity Testing
}

D. H. Miller

M. M. Reigel

September 2012

Savannah River National Laboratory Savannah River Nuclear Solutions, LLC Aiken, SC 29808

Prepared for the U.S. Department of Energy under contract number DE-AC09-08SR22470. 
SRNL-STI-2012-00551

Revision 0

\section{DISCLAIMER}

This work was prepared under an agreement with and funded by the U.S. Government. Neither the U.S. Government or its employees, nor any of its contractors, subcontractors or their employees, makes any express or implied:

1. warranty or assumes any legal liability for the accuracy, completeness, or for the use or results of such use of any information, product, or process disclosed; or

2. representation that such use or results of such use would not infringe privately owned rights; or

3. endorsement or recommendation of any specifically identified commercial product, process, or service.

Any views and opinions of authors expressed in this work do not necessarily state or reflect those of the United States Government, or its contractors, or subcontractors.

\section{Printed in the United States of America \\ Prepared for U.S. Department of Energy}


Keywords: Saltstone, Formed Core Sampler, Hydraulic

Conductivity

Retention: Permanent

\section{Formed Core Sampler Hydraulic Conductivity Testing}

D. H. Miller

M. M. Reigel

September 2012

Savannah River National Laboratory

Savannah River Nuclear Solutions, LLC

Aiken, SC 29808

Prepared for the U.S. Department of Energy under contract number DE-AC09-08SR22470. 


\section{REVIEWS AND APPROVALS}

AUTHORS:

D. H. Miller, Engineering Process Development

Date

M. M. Reigel, Engineering Process Development

Date

TECHNICAL REVIEW:

P. M. Almond, Engineering Process Development Date

APPROVAL:

K. M. Fox, Manager

Date

Engineering Process Development

S. L. Marra, Manager

Date

Environmental \& Chemical Process Technology Research Programs

K. H. Rosenberger, Manager

Date

Closure and Disposal Assessment 


\section{EXECUTIVE SUMMARY}

A full-scale formed core sampler was designed and functionally tested for use in the Saltstone Disposal Facility (SDF). Savannah River National Laboratory (SRNL) was requested to compare properties of the formed core samples and core drilled samples taken from adjacent areas in the full-scale sampler. While several physical properties were evaluated, the primary property of interest was hydraulic conductivity. Differences in hydraulic conductivity between the samples from the formed core sampler and those representing the bulk material were noted with respect to the initial handling and storage of the samples. Due to testing conditions, the site port samples were exposed to uncontrolled temperature and humidity conditions prior to testing whereas the formed core samples were kept in sealed containers with minimal exposure to an uncontrolled environment prior to testing. Based on the results of the testing, no significant differences in porosity or density were found between the formed core samples and those representing the bulk material in the test stand. 


\section{TABLE OF CONTENTS}

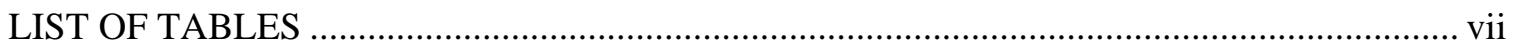

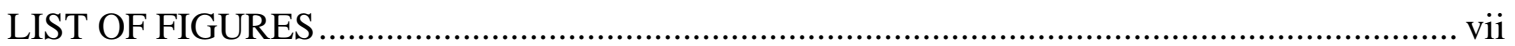

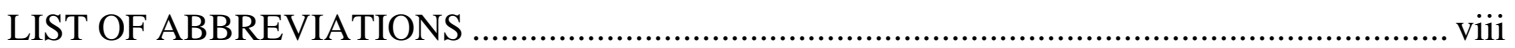

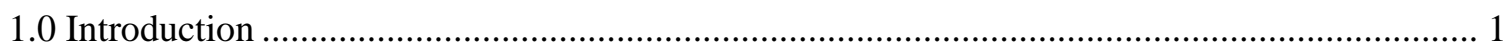

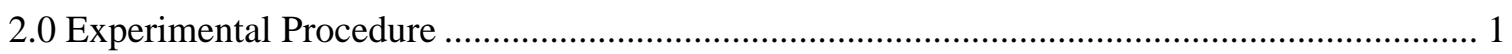

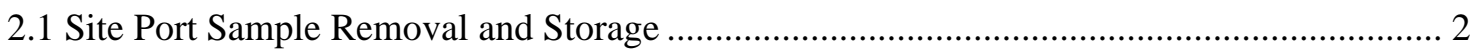

2.2 Formed Core Sample Removal and Storage ..................................................................... 3

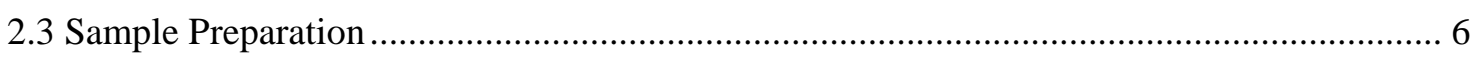

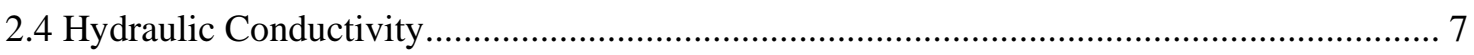

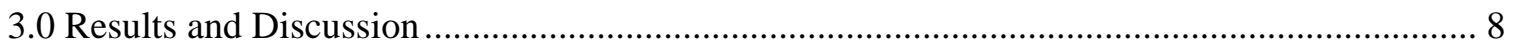

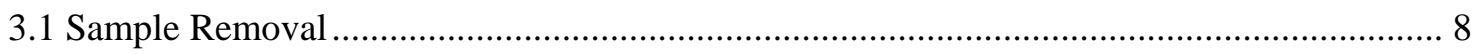

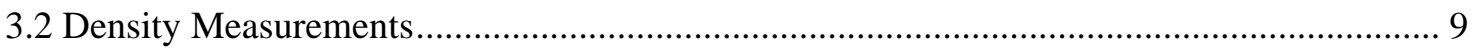

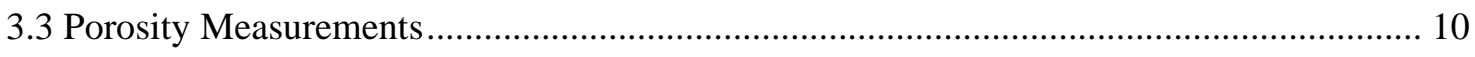

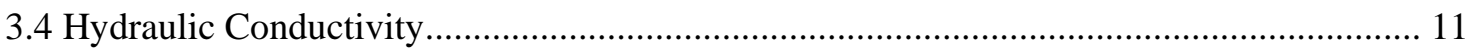

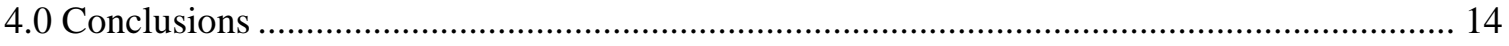

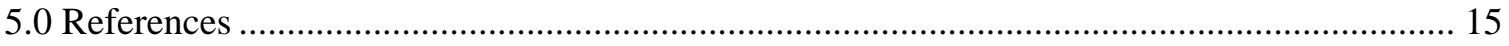




\section{LIST OF TABLES}

Table 2-1. Formed Core Testing Timeline .................................................................................. 1

Table 2-2. Simple Tank 50 Based Salt Solution Batch Sheet. .................................................... 5

Table 3-1. Extraction of Formed Core Samples from Vials........................................................ 9

Table 3-2. Density Results for Formed Core and Sight Port Samples. ..................................... 10

Table 3-3. Moisture Results on Formed Core and Site Port Samples ......................................... 10

Table 3-4. Formed Core Sample Vial Hydraulic Conductivity Results. ..................................... 12

Table 3-5. Site Port Sample Hydraulic Conductivity Results. …............................................. 12

\section{LIST OF FIGURES}

Figure 2-1. Test Stand and Expanded Sampler Vial View.......................................................... 2

Figure 2-2. Site Port Core Drill Set Up................................................................................ 3

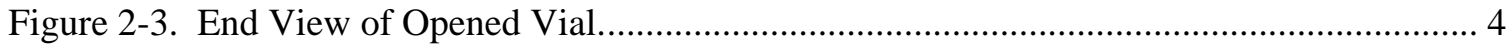

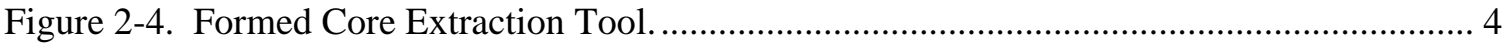

Figure 2-5. Typical Formed Core Sample Label Scheme …..................................................... 6

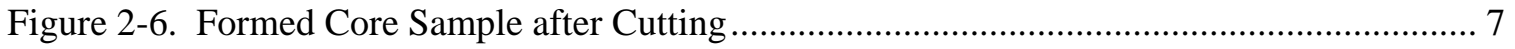

Figure 2-7. Formed Core End Piece after Cutting .................................................................... 7

Figure 3-1. Macrographs of Site Port and Formed Core Vial Samples...................................... 11

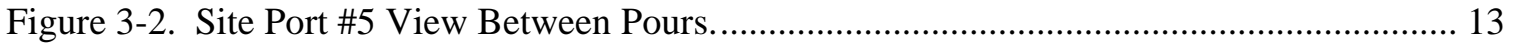




\section{LIST OF ABBREVIATIONS}

$\begin{array}{ll}\text { ASTM } & \text { American Society for Testing and Materials } \\ \text { C\&WDA } & \text { Closure and Waste Disposal Authority } \\ \text { PA } & \text { Performance Assessment } \\ \text { SDF } & \text { Saltstone Disposal Facility } \\ \text { SDU } & \text { Saltstone Disposal Unit } \\ \text { SRNL } & \text { Savannah River National Laboratory }\end{array}$




\subsection{Introduction}

Saltstone Engineering has requested demonstration of a full-scale remote formed core grout sampling device that could be implemented in a future Saltstone Disposal Unit (SDU) in the Saltstone Disposal Facility (SDF). This grout sampling method would be used to obtain samples of the cured, low-level cementious waste form without employing traditional methods like core drilling. The full-scale fabrication and testing of the formed core sampling system is documented elsewhere. ${ }^{1}$

Savannah River National Laboratory (SRNL) was requested by Closure and Waste Disposal Authority (C\&WDA) to analyze the simulated samples collected during the full-scale testing of the formed core sampler. Based on the information requested in the Technical Task Request, ${ }^{2}$ a Task Technical and Quality Assurance Plan $^{3}$ was developed outlining the approach. As will be described in the following sections, physical properties including hydraulic conductivity, porosity, and density were measured on samples removed from the formed core vials. These results were compared to samples that were core drilled from site ports near the vials in the test stand.

\subsection{Experimental Procedure}

Details of how the formed core samplers were filled and removed from the test stand are documented in a previous report. ${ }^{1}$ This report focuses on removing the simulated saltstone samples from the formed core samplers, storage and handling, and subsequent analysis. The samples removed from the cured grout surrounding the formed cores are referred to as "site port samples." The formed core vials were labeled 1 through 6, corresponding to the order they were filled. Therefore, the saltstone in vial \#1 was placed first and it was the last vial to be removed from the full-scale piping. A general time line of the testing activities is shown in Table 2-1. A picture of the test stand and an expanded view of the internal components are shown in Figure 2-1.

Table 2-1. Formed Core Testing Timeline

\begin{tabular}{|c|c||}
\hline Activity & Date \\
\hline Test Stand Vial Filling & July 2011 \\
\hline Sample Vial Removal & October 2011 \\
\hline Site Port Core Drilling & December 2011 \\
\hline Site Port Sectioning & March 2012 \\
\hline Formed Core Sample Removal & April 2012 \\
\hline Formed Core Sample Sectioning & May 2012 \\
\hline Hydraulic Conductivity Testing & June 2012 \\
\hline
\end{tabular}




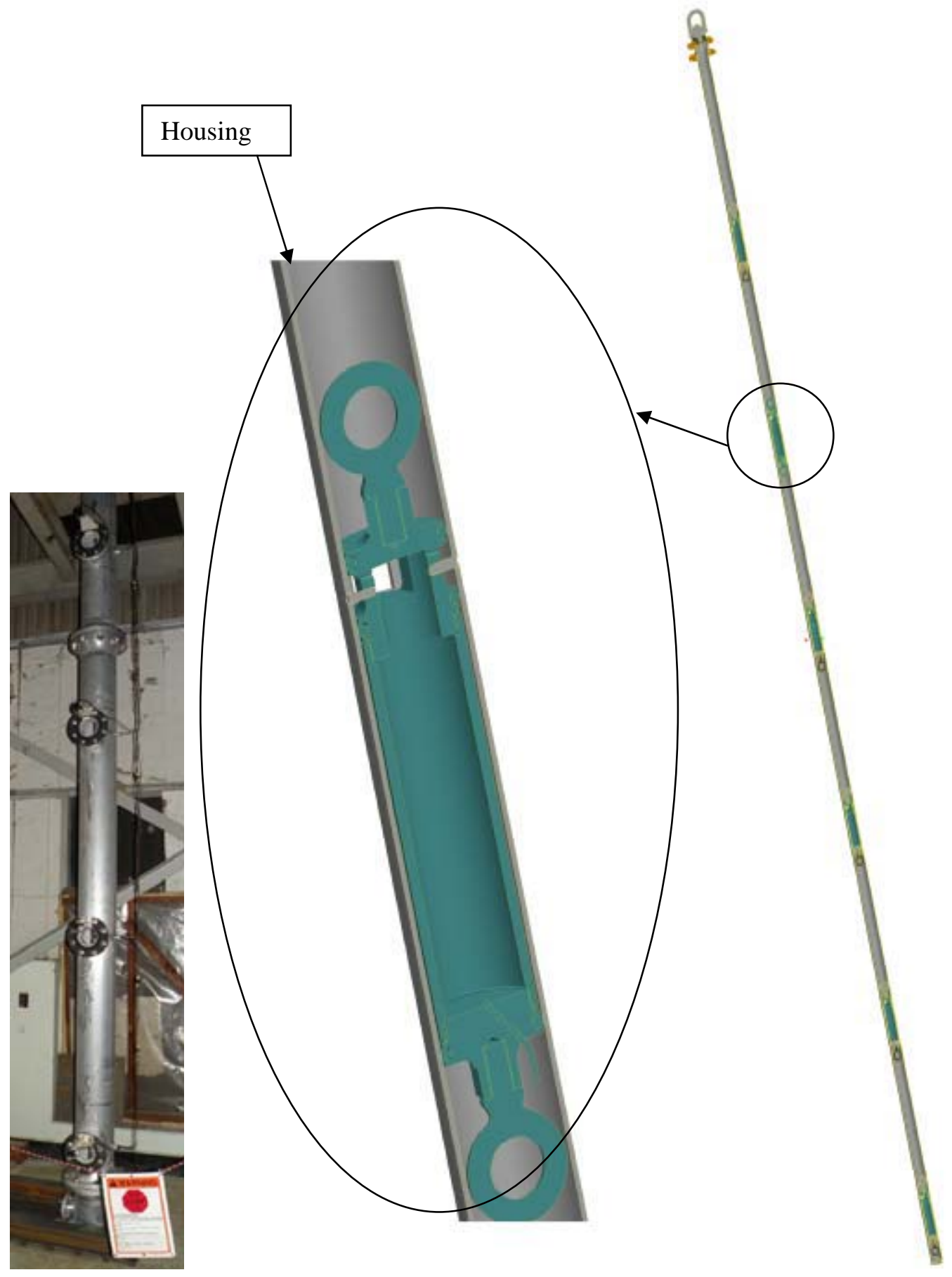

Figure 2-1. Test Stand and Expanded Sampler Vial View.

\subsection{Site Port Sample Removal and Storage}

After the vials were removed from the test stand, it was cut into sections. Samples were core drilled out of each of the six site port locations. The same two inch diameter core bit used in the 2009 Vault 4 sampling study ${ }^{4}$ was chosen since it had proven to be effective and also provided a 
sample suitable for hydraulic conductivity testing. ${ }^{5}$ Most site ports provided two samples approximately three inches long taken from the center of the port. Some locations only yielded one viable sample with the remaining section being broken into small pieces. The device used for the core drilling is shown in Figure 2-2. The core drilled samples were initially sealed in plastic bags. Damp cloths were subsequently added to the bags and the samples were stored in a sealed humidity box. The chamber is not controlled to a specific value but maintains a high humidity condition.

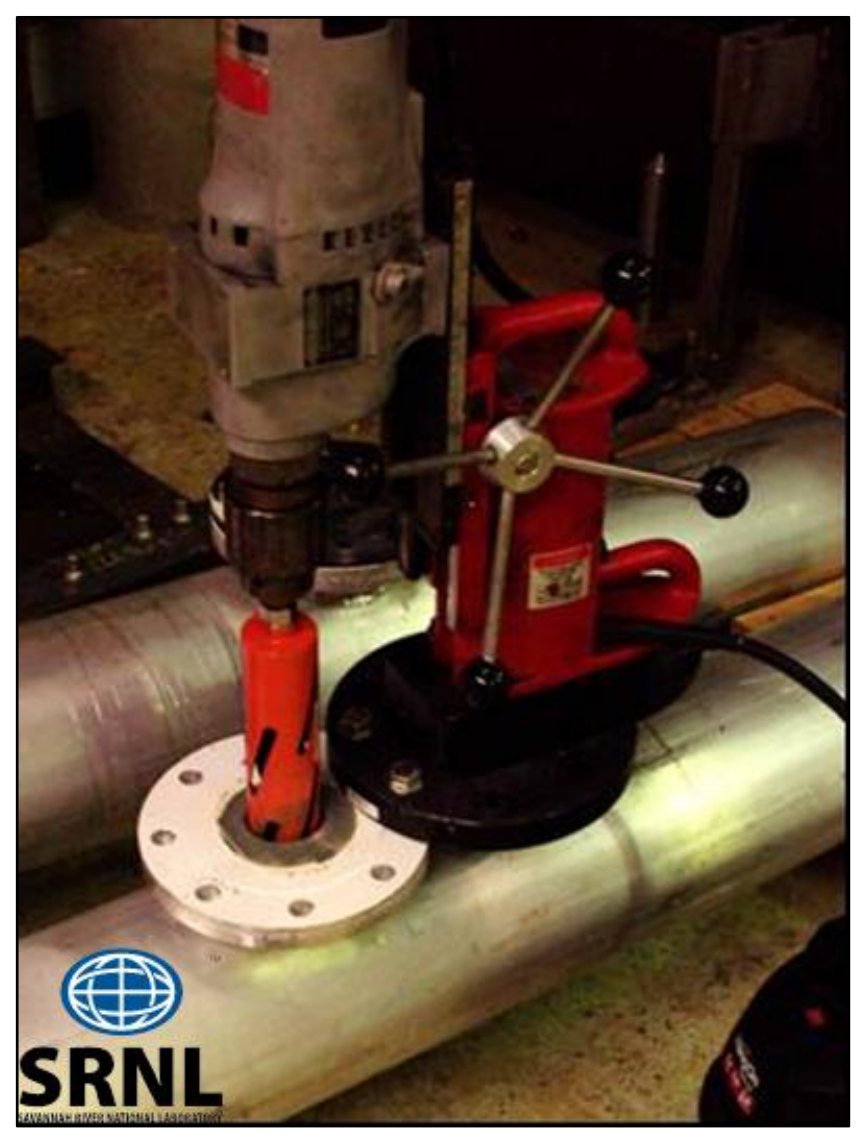

Figure 2-2. Site Port Core Drill Set Up.

\subsection{Formed Core Sample Removal and Storage}

Formed core sample vial removal was addressed in the full-scale test report. When the sample vials were removed from the piping, a Lexan sleeve was placed over the exposed grout to preserve the samples (e.g., prevent the samples from drying out) during storage. The vials were stored in a plastic case at ambient conditions in an SRNL laboratory. A sample removal tool had been designed to slowly push the sample out of the vials. After the end caps were removed from sample vial \#1, the motor did not have sufficient torque to push the sample out of the vial. The caps were replaced and vial 2 was opened. This sample came out easily. It was determined that the remaining samples would require additional force and the removal process was delayed until an arbor press was available. A large force was required to initiate sample movement which was then followed with the extraction tool. The end of the sample vial containing the thermocouple lead is shown in Figure 2-3 after the removal of the end cap. Photographs of all samples during removal from the vials are in Appendix A. 


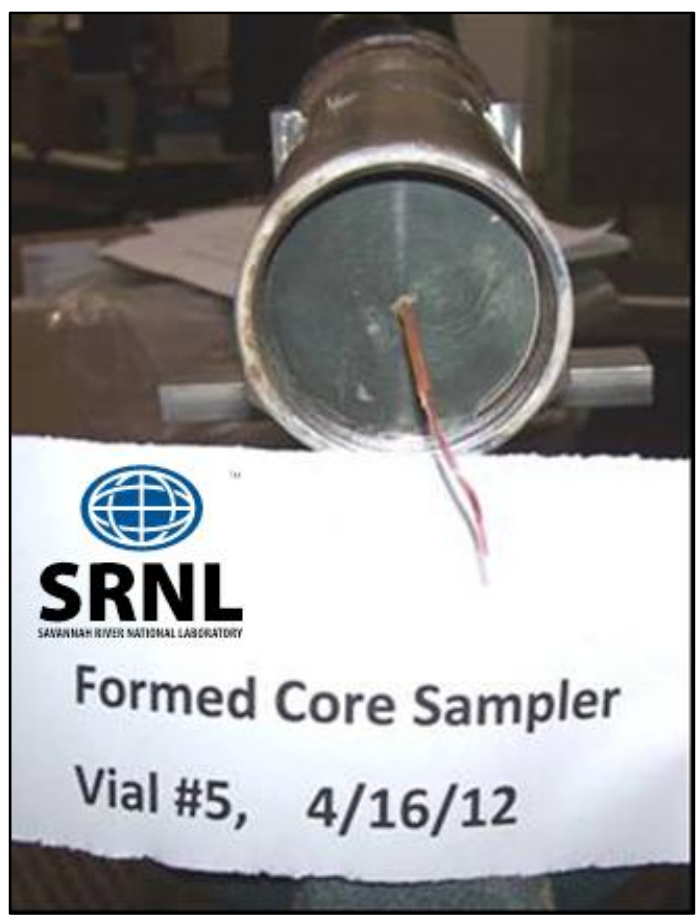

Figure 2-3. End View of Opened Vial.

A sample being removed with the extraction tool is shown in Figure 2-4. The sample is pushed out of the vial into a clear PVC tube. This maintains the integrity of the sample for transfer to the storage cylinder.

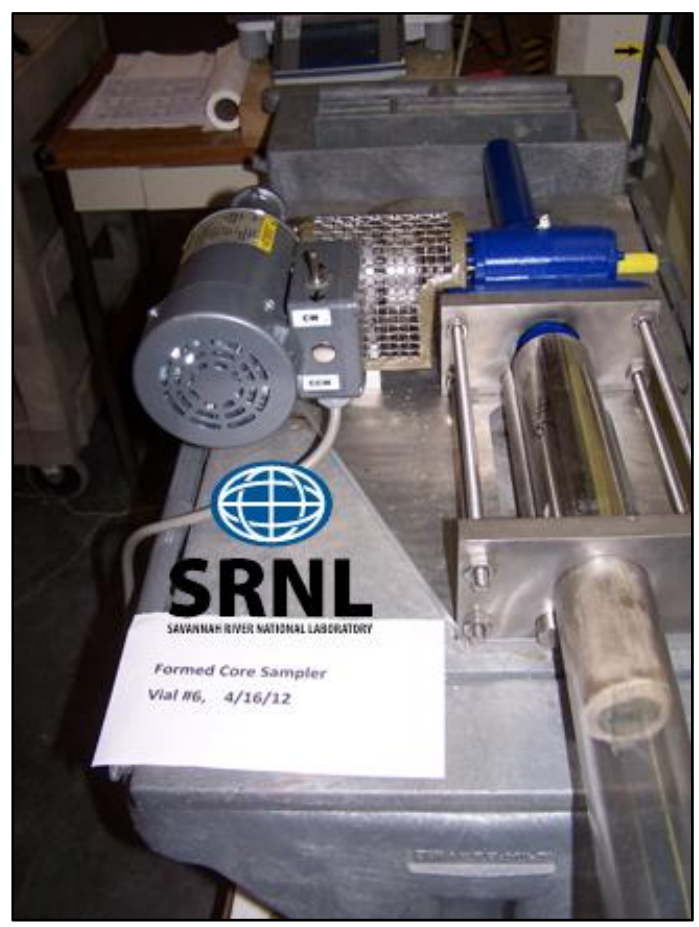

Figure 2-4. Formed Core Extraction Tool. 
After removal, each sample was photographed, weighed, measured, and immediately placed in a cylinder containing a simplified Tank 50 salt solution. The composition of the salt solution, shown in Table 2-2, was chosen since it does not include reactive species such as aluminum nitrate or phosphates. This was used to avoid interactions of the test fluid and the sample during storage and subsequent testing. The storage cylinder is designed to keep the sample under approximately 22 inches of mercury vacuum. This aids in the saturation of the sample prior to hydraulic conductivity testing.

Table 2-2. Simple Tank 50 Based Salt Solution Batch Sheet.

\begin{tabular}{||c|c|c||}
\hline Order of Addition & Chemical & Grams \\
\hline 1 & $50 \%$ by Weight $\mathrm{NaOH}$ & 609 \\
\hline 2 & $\mathrm{DI} \mathrm{H}_{2} \mathrm{O}$ & 1050 \\
\hline 3 & $\mathrm{Na}_{2} \mathrm{CO}_{3}$ & 65.27 \\
\hline 4 & $\mathrm{NaNO}_{3}$ & 702 \\
\hline 5 & $\mathrm{NaNO}_{2}$ & 132.82 \\
\hline 6 & $\mathrm{DI} \mathrm{H}_{2} \mathrm{O}$ & 1780.87 \\
\hline \multicolumn{2}{|c|}{ Average Total Solids } & 4339.96 \\
\hline \multicolumn{2}{|c|}{ Average Density } & $28.33 \mathrm{wt} \%$ \\
\hline
\end{tabular}

The labeling plan for the formed core samples is shown in Figure 2-5. This indicates the approximate location of each sub sample in relation to the entire sample. As will be seen in later tables, not all samples could be cut to the exact desired length, but the targeted values are shown for reference. 


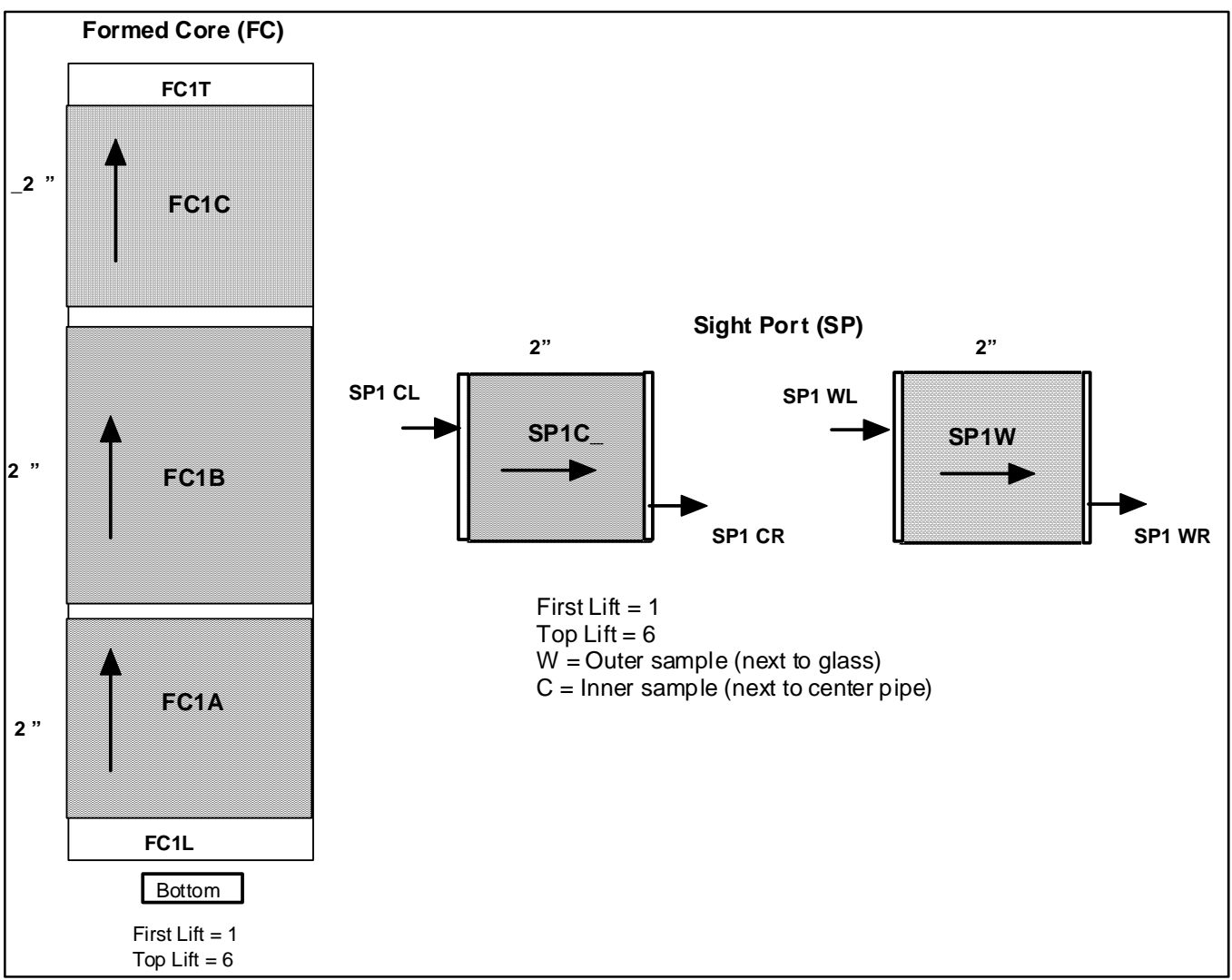

Figure 2-5. Typical Formed Core Sample Label Scheme

\subsection{Sample Preparation}

Samples for hydraulic conductivity (ASTM D5084) ${ }^{6}$ require a cylinder with an aspect ratio of at least one to one. The formed core and site port samples were hand cut using a miter box saw to insure that the ends were flat and parallel. The formed core samples were removed from the storage cylinder for cutting and then returned to the cylinders for storage under slight vacuum in salt solution. The site port samples were taken from the plastic bag, cut, and then stored in salt solution. A typical sample after cutting is shown in Figure 2-6. Approximately a quarter inch of material was removed from each sample end prior to cutting the two or three inch long samples for hydraulic conductivity testing. This was done to expose a fresh surface and to remove any tapering that may have occurred on the end of the sample. The majority of samples were cut to two inches long, but several were longer in an attempt to determine any impact of aspect ratio on hydraulic conductivity measurements. One site port sample (SP6W) was 1.4 inches long due to sample breakage during core drilling.

The end disks from the formed core samples were placed back in salt solution prior to density and porosity testing. The site port sample ends were also broken into smaller pieces for density and porosity measurements. A typical end piece is shown in Figure 2-7. The end pieces were broken into smaller pieces (approximately one half inch squares) for density measurements. Density was measured using a Quantachrome Instruments gas pycnometer to determine the structural or true density of a material and differs from the bulk density of a sample. The moisture content was measured using a Mettler Toledo halogen moisture analyzer. The measured moisture content was used to calculate the porosity of the sample. The mass loss was monitored until no further mass 
loss occurred. The water released during heating is converted to a volume of simulant by dividing by the ratio of the mass of water to the mass of the simulant then dividing again by the density of the simulant (Table 2-2). Porosity was then calculated by dividing the volume of simulant by the volume of grout which was determined from the bulk density.

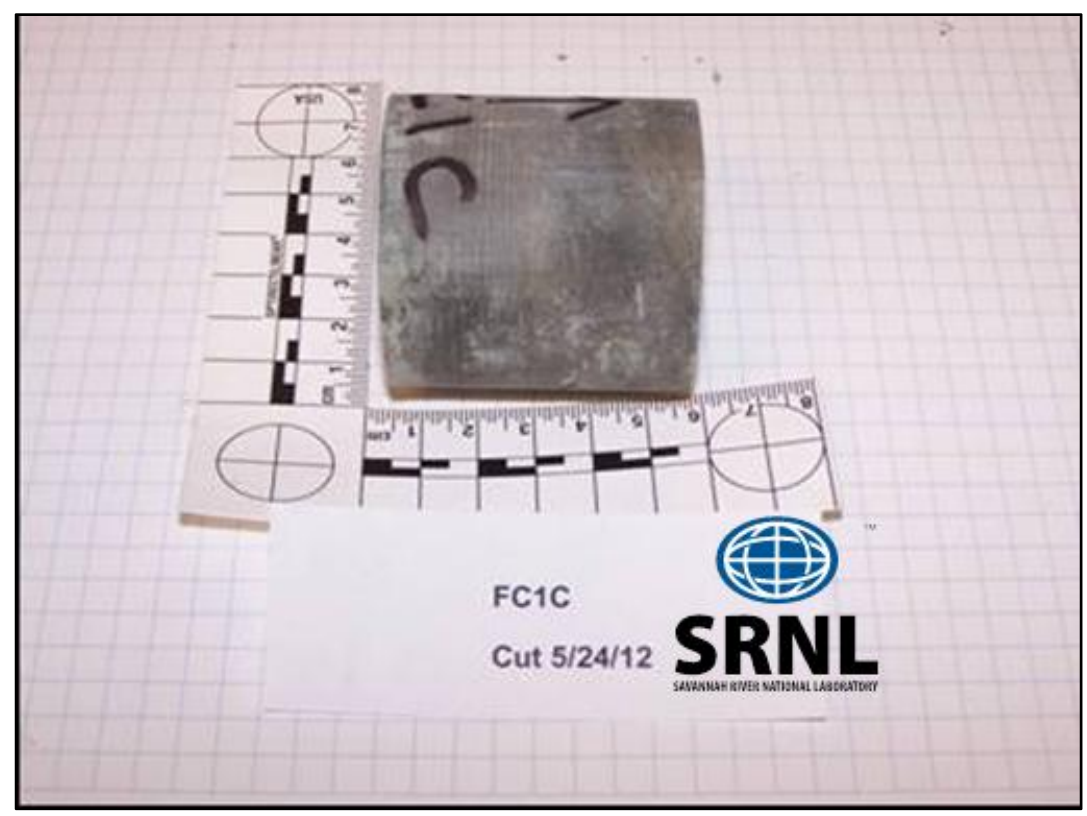

Figure 2-6. Formed Core Sample after Cutting

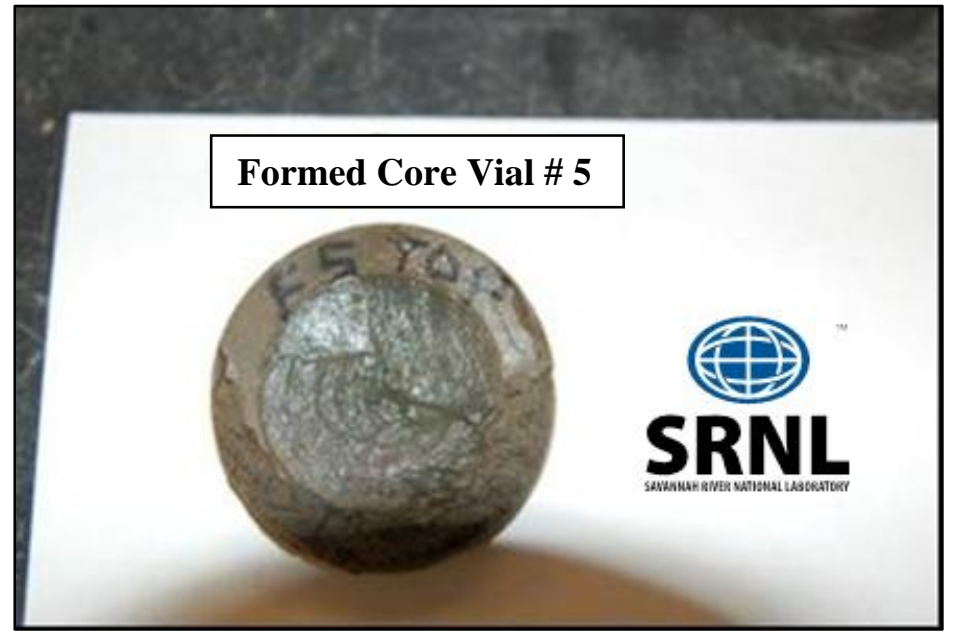

Figure 2-7. Formed Core End Piece after Cutting

\subsection{Hydraulic Conductivity}

The permeability of saltstone in the SDUs is one of the significant properties affecting the Performance Assessment (PA) for saltstone. ASTM D5084- Method F was used to determine the hydraulic conductivity or permeability of the sample. Representative samples from both the 
formed core vials and the site ports were submitted to an outside testing laboratory ${ }^{*}$ for hydraulic conductivity measurements. Each sample was identified, weighed, measured, and photographed prior to shipment to the vendor. The samples were placed in individual containers that allowed the simple Tank 50 salt solution to cover the material completely during shipment and prior to testing. This prevented drying and aided in achieving the necessary saturation prior to testing.

\subsection{Results and Discussion}

\subsection{Sample Removal}

As noted in Section 2.2, a larger than expected force was required to initiate removal of the majority of the formed core samples. This is shown in Table 3-1 along with a brief description of each sample. The excessive force of up to 13 tons may be due to the inside sample vials not being electro-polished as recommended in the formed core proof-of-concept testing report. ${ }^{7}$ It is difficult to verify the surface condition of the empty vials after sample removal, but lack of electro polishing has proven to make sample extraction difficult. During the proof-of-concept testing, at least one vial was electro-polished and it was shown that sample extraction required minimal or no force. It is likely that one of these samplers was used in the full-scale testing, which is why vial \#2 required essentially no force to remove the formed core sample.

As noted in Table 3-1, the samples were mostly dark in color when removed from the sample vial, indicating little or no drying of the samples. Any lighter color noted in Table 3-1 is due to the removal of the end caps during the first attempt at removing the samples. Removing the end caps broke the seal keeping the samples saturated in the vial, causing some samples to have a lighter outside color, especially at the top of the sample. Once extracted from the vial, the samples were observed to visibly change to a lighter color while exposed to the environment while the sample dimensions and weight were being measured. These measurements were performed quickly and the samples were immersed in salt solution as soon after extraction as possible.

\footnotetext{
* Amec E\&I (formerly MacTec) 396 Plasters Ave, Atlanta Ga, 30324
} 
Table 3-1. Extraction of Formed Core Samples from Vials.

\begin{tabular}{|c|c|c|c|c|}
\hline $\begin{array}{l}\text { Sample } \\
\text { ID }\end{array}$ & $\begin{array}{l}\text { Sample } \\
\text { Mass in } \\
\text { PVC } \\
\text { Sleeve } \\
\text { (grams) }\end{array}$ & $\begin{array}{l}\text { Sample } \\
\text { Length } \\
\text { (inches) }\end{array}$ & $\begin{array}{c}\text { Initial } \\
\text { Extraction } \\
\text { Force } \\
\text { (tons) }\end{array}$ & Comments/Conditions \\
\hline F1 & 923.9 & 8 & 11 & $\begin{array}{l}\text { Pushed from one end, no movement but noticed } \\
\text { liquid squeezing out. Switched ends and applied } \\
\text { series of } 5-7 \text { ton bumps. Switched to extractor for } \\
\text { final removal. Sample was dark green. Bottom } 0.25 \\
\text { inches broke during removal. }\end{array}$ \\
\hline F2 & 926.7 & $7-3 / 4$ & 0 & $\begin{array}{l}\text { Pushed out easily by hand. Dark brown/green in } \\
\text { color. Did not appear to be dried. }\end{array}$ \\
\hline F3 & 915.3 & 8 & 12 & $\begin{array}{l}\text { Only pushed from bottom end, then to extractor. } \\
\text { The top } 0.25 \text { inches were gray and appeared to be } \\
\text { drier. Remaining sample was dark gray/green. }\end{array}$ \\
\hline F4 & 920.8 & $7-7 / 8$ & 13 & $\begin{array}{l}\text { Pushed from bottom only. Light gray on top } \\
0.25 \text { inches. Dark green elsewhere. }\end{array}$ \\
\hline F5 & 922.3 & 8 & 4 & Pushed from bottom only. Overall light color. \\
\hline F6 & 901.7 & 8 & 10 & $\begin{array}{l}\text { Pushed from bottom only. Lighter color overall; } \\
\text { gray. }\end{array}$ \\
\hline
\end{tabular}

\subsection{Density Measurements}

A Quantachrome Instruments gas pycnometer was used to calculate the structural or true density of the samples. The pycnometer measures the volume of material which is inaccessible to the gas used (helium). It is important to note that the results vary depending on the type of gas used. Therefore, open porosity, microcracks, etc. are not included in the structural density measurement; however, closed porosity inaccessible to the helium gas or non-porous hydration products are included in the structural density calculation. Initially it was difficult to obtain repeatable readings for the volume of the sample. After multiple calibrations it was determined that saturated rather than dried samples yielded much more repeatable results. In addition, the results could be compared to the dried bulk density values obtained as part of the hydraulic conductivity testing. The results of the density measurements are shown in Table 3-2. It should be noted that the bulk density results, calculated from the total volume of the grout cylinder, are approximately $0.2 \mathrm{~g} / \mathrm{cc}$ lower, as this does not account for any sample porosity. The helium gas in the pycnometer can penetrate even the small pores, which yields a lower calculated material volume and therefore a higher density. As shown in Table 3-2, the values for the formed core and site port samples are similar when measured at the same location. Both density measurements result in comparable values between the formed core and site port samples. This indicates that there are no significant material differences between the formed core sample and the surrounding saltstone in the SDU. 
Table 3-2. Density Results for Formed Core and Sight Port Samples.

\begin{tabular}{|c|c|c|c|c|c|}
\hline $\begin{array}{l}\text { Formed Core } \\
\text { Sample } \\
\text { ID }\end{array}$ & $\begin{array}{l}\text { Bulk } \\
\text { Density } \\
\text { (g/cc) }\end{array}$ & $\begin{array}{c}\text { Structural } \\
\text { Density } \\
\text { (g/cc) }\end{array}$ & $\begin{array}{c}\text { Site Port } \\
\text { Sample } \\
\text { ID }\end{array}$ & $\begin{array}{c}\text { Bulk } \\
\text { Density } \\
\text { (g/cc) }\end{array}$ & $\begin{array}{l}\text { Structural } \\
\text { Density } \\
\text { (g/cc) }\end{array}$ \\
\hline FC1A & 1.77 & $\mathrm{~nm}$ & \multirow{2}{*}{ SP1W } & \multirow{2}{*}{1.73} & \multirow{2}{*}{1.97} \\
\hline FC1C & 1.77 & 1.99 & & & \\
\hline FC2A & 1.76 & $\mathrm{~nm}$ & \multirow{2}{*}{ SP2W } & \multirow{2}{*}{1.77} & \multirow{2}{*}{1.77} \\
\hline FC2C & 1.75 & 1.88 & & & \\
\hline FC3B & 1.73 & 2.15 & SP3W & 1.72 & 1.92 \\
\hline FC4A & 1.77 & $\mathrm{~nm}$ & \multirow{2}{*}{ SP4W } & \multirow{2}{*}{1.73} & \multirow{2}{*}{2.07} \\
\hline FC4C & 1.73 & 2.13 & & & \\
\hline FC5B & 1.75 & $\mathrm{~nm}$ & \multirow{2}{*}{ SP5W } & \multirow{2}{*}{1.75} & \multirow{2}{*}{1.98} \\
\hline FC5C & 1.75 & 1.99 & & & \\
\hline FC6C & 1.73 & 1.91 & SP6W & 1.73 & 1.87 \\
\hline Average & 1.75 & 2.01 & Average & 1.74 & 1.93 \\
\hline
\end{tabular}

$\mathrm{nm}=$ not measured

\subsection{Porosity Measurements}

The porosity of the samples was calculated using the moisture content measured by the Mettler Toledo HR83 Moisture Analyzer. This method is based on previous work establishing a relationship between mass loss due to drying (moisture content) and the porosity of the sample. ${ }^{8}$ A set of small samples measured at SRNL were compared to the moisture results provided by the vendor as part of the hydraulic conductivity testing. The values were similar, therefore the vendor readings are used to calculate the porosity values (Table 3-3) since the same sample was measured for both hydraulic conductivity and porosity. The values are similar with the site port being slightly lower on average. This is a result of the difference in storage methods required for the two sets of samples. Also, during dismantling of the full-scale formed core set up, the grout surrounding the formed core pipe was exposed to the environment for many weeks leading to drying of the simulated saltstone.

Table 3-3. Moisture Results on Formed Core and Site Port Samples.

\begin{tabular}{|c|c|c|c||}
\hline $\begin{array}{c}\text { Formed Core } \\
\text { Sample ID }\end{array}$ & $\begin{array}{c}\text { Porosity } \\
\mathbf{( \% )}\end{array}$ & $\begin{array}{c}\text { Site Port } \\
\text { Sample ID }\end{array}$ & $\begin{array}{c}\text { Porosity } \\
\mathbf{( \% )}\end{array}$ \\
\hline FC1A & 62.7 & SP1W & 60.7 \\
\hline FC1C & 63.5 & SP2W & 60.6 \\
\hline FC2A & 63.1 & SP3W & 59.3 \\
\hline FC2C & 61.2 & SP4W & 59.3 \\
\hline FC3B & 61.5 & SP5W & 59.6 \\
\hline FC4A & 62.3 & SP6W & 58.7 \\
\hline FC4C & 59.9 & \multicolumn{2}{|}{} \\
\cline { 1 - 2 } FC5B & 61.6 & & \\
\hline FC5C & 61.6 & & \\
\hline FC6C & 63.0 &
\end{tabular}

As an additional check on the two types of samples, several pieces were viewed under an optical microscope. No polishing was used to prepare the samples, but similar flat portions were chosen for comparison. There were no significant differences found in the limited number of samples 
studied. This was expected since the density and porosity values were comparable. Representative macrographs of a site port and a vial sample are shown in Figure 3-1.
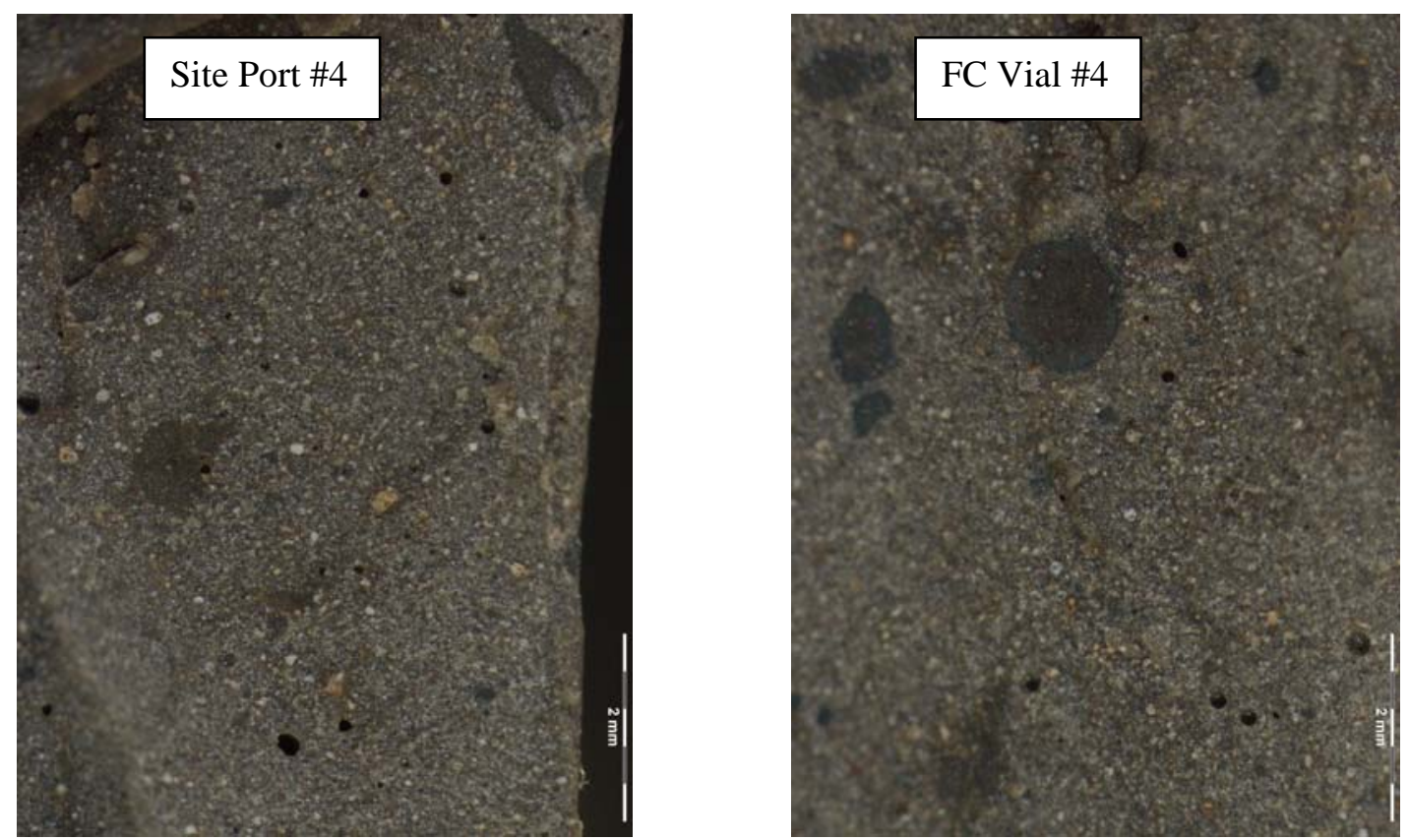

Figure 3-1. Macrographs of Site Port and Formed Core Vial Samples.

\subsection{Hydraulic Conductivity}

The results of the vendor hydraulic conductivity testing are shown in Table 3-4 and Table 3-5, along with any comments recorded during the preparation at SRNL. As noted in Section 2.4, the samples were shipped to the vendor in a simplified salt solution. In addition, most samples had been stored under vacuum in salt solution prior to sectioning. This shortened the duration of the pre-conditioning associated with the test procedure. As required by the ASTM method, samples are kept in the test cell until two consecutive readings meet the equilibrium criteria and having the samples in a saturated condition reduces the overall test duration. This requirement can lead to test durations that vary widely within a set of samples. 
Table 3-4. Formed Core Sample Vial Hydraulic Conductivity Results.

\begin{tabular}{|c|c|c|c|}
\hline Sample ID & Location & $\begin{array}{c}\text { Hydraulic } \\
\text { Conductivity } \\
\text { (cm/sec) }\end{array}$ & Comments \\
\hline FCIA & $\begin{array}{c}\text { First Vial } \\
\text { Bottom Section }\end{array}$ & $3.6 \times 10^{-9}$ & - \\
\hline FC1C & $\begin{array}{c}\text { First Vial } \\
\text { Top Section }\end{array}$ & $1.9 \times 10^{-9}$ & - \\
\hline FC2A & $\begin{array}{c}\text { Second Vial } \\
\text { Bottom Section }\end{array}$ & $3.3 \times 10^{-10}$ & - \\
\hline FC2C & $\begin{array}{l}\text { Second Vial } \\
\text { Top Section }\end{array}$ & $3.5 \times 10^{-7}$ & $\begin{array}{l}3 \times 2 \text { in. sample } \\
\text { Cracks on } 1 \text { side }\end{array}$ \\
\hline FC3B & $\begin{array}{c}\text { Third Vial } \\
\text { Top Section }\end{array}$ & $1.4 \times 10^{-10}$ & - \\
\hline FC4A & $\begin{array}{c}\text { Forth Vial } \\
\text { Bottom Section }\end{array}$ & $3.2 \times 10^{-8}$ & Cracks on 1 side \\
\hline FC4C & $\begin{array}{c}\text { Forth Vial } \\
\text { Top Section }\end{array}$ & $1.8 \times 10^{-9}$ & $3 \times 2$ in. sample \\
\hline FC5B & $\begin{array}{c}\text { Fifth Vial } \\
\text { Middle Section }\end{array}$ & $8.9 \times 10^{-7}$ & $\begin{array}{c}3 \times 2 \text { in. sample } \\
\text { Cracks on side }\end{array}$ \\
\hline FC5C & $\begin{array}{c}\text { Fifth Vial } \\
\text { Top Section }\end{array}$ & $1.4 \times 10^{-8}$ & - \\
\hline FC6C & $\begin{array}{c}\text { Sixth Vial } \\
\text { Top Section }\end{array}$ & $1.4 \times 10^{-8}$ & - \\
\hline
\end{tabular}

Table 3-5. Site Port Sample Hydraulic Conductivity Results.

\begin{tabular}{|c|c|c|c||}
\hline Sample ID & Location & $\begin{array}{c}\text { Hydraulic } \\
\text { Conductivity } \\
\text { (cm/sec) }\end{array}$ & Comments \\
\hline SP1W & $\begin{array}{c}\text { First Site } \\
\text { Port }\end{array}$ & $3.1 \times 10^{-8}$ & - \\
\hline SP2W & $\begin{array}{c}\text { Second } \\
\text { Site Port }\end{array}$ & $3.8 \times 10^{-9}$ & - \\
\hline SP3W & $\begin{array}{c}\text { Third Site } \\
\text { Port }\end{array}$ & $5.1 \times 10^{-9}$ & - \\
\hline SP4W & $\begin{array}{c}\text { Fourth Site } \\
\text { Port }\end{array}$ & $2.5 \times 10^{-7}$ & - \\
\hline SP5W & $\begin{array}{c}\text { Fifth Site } \\
\text { Port }\end{array}$ & $3.2 \times 10^{-7}$ & 1.4 in. by 2.0 in. \\
sample
\end{tabular}

In general, the two sets of samples are similar with both showing a range of values. All values ranged from $10^{-7}$ to $10^{-10} \mathrm{~cm} / \mathrm{sec}$. When the reported values are averaged without regard to visual or other potential differences, the hydraulic conductivity of the formed core and site port samples are $1.3 \times 10^{-7}$ and $1.0 \times 10^{-7} \mathrm{~cm} / \mathrm{sec}$, respectively; however, some samples had visible defects that account for the higher reported values that skew the average. Therefore, the corresponding formed core and site port samples should be individually compared. 
As shown in Figure 2-2 and Figure 3-2, some of the faster conductivity rates are explained by the pouring sequence. The site port samples were drilled such that hydraulic conductivity measurements have the permeant flow parallel to the direction the saltstone filled the site port. If there were any effect of layering, the flow of the permeant relative to the layers could lead to faster hydraulic conductivities. For example, site port \#5 was core drilled from a section in the test stand that had a five day gap between pours. This resulted in a cold joint in the sample parallel to the direction of flow during testing. Photographs of the window after the first pour and at the start of the second pour are shown in Figure 3-2. Site port \#5 also had the lowest moisture content of all the samples, which could indicate that additional drying had occurred during the sampling and storage process. As noted in Table 3-4, some of the samples had visible cracks on the side, most likely due to the large extraction forces applied in removing them from the vials. These fast paths for flow would result in a high bias for the reported hydraulic conductivity of that sample.
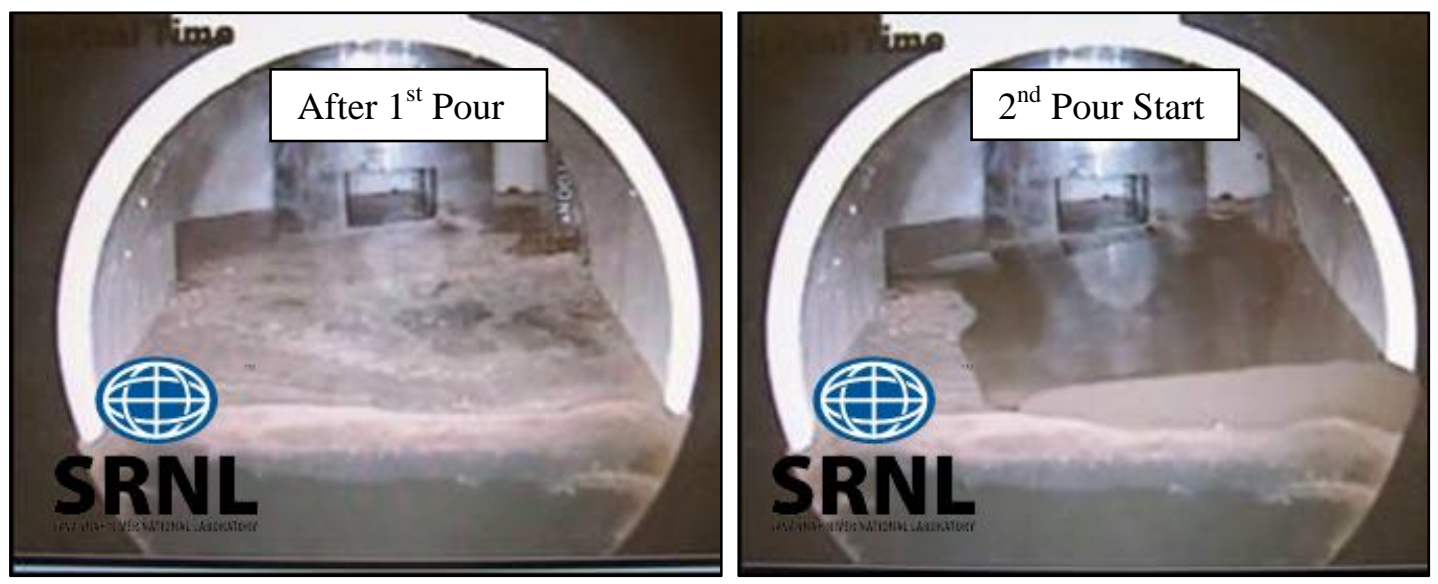

Figure 3-2. Site Port \#5 View Between Pours.

Due to the limited number of samples, it is difficult to determine any effect caused by the sample aspect ratio. Hydraulic conductivity values on the order of $10^{-9} \mathrm{~cm} / \mathrm{sec}$ were obtained with samples above and below the standard ratio of 2:1. Other samples with higher aspect ratios had visible cracks that may have reduced the measured values. Additional samples could be run to determine the effect of aspect ratio on the hydraulic conductivity measurements of saltstone. 


\subsection{Conclusions}

The results of the study indicate that the formed core sampler produced samples that were representative of the adjacent saltstone in the test stand for density and porosity. There were inherent differences in how the formed core and site port samples were handled and stored due to the nature of the test. The formed core samples were kept in sealed vials prior to testing while the site port samples were left in an uncontrolled environment until they were drilled out of the test stand. In addition, the site port samples were drilled parallel to the direction of saltstone flow during pouring, causing the hydraulic conductivity measurements to be performed such that the permeant flow was parallel to any layers that may have formed in the sample during placement. Therefore, any discrepancy between the formed core and site port samples is due to cracking in one of the samples, the pour schedule while filling the full-scale formed core test stand, and exposure to an uncontrolled environment prior to testing. The formed core samples had slightly lower hydraulic conductivities than the adjacent SDU material. 


\subsection{References}

1 Coughlin, J. T., Miller, D. H., "Full-Scale Testing of the Formed Core Sampler for Saltstone Facility Vaults”, SRNL-STI-2011-00706 Rev 0, December 12, 2011

2. Smith, F. M. “Technical Task Request- Perform Saturated Hydraulic Conductivity Measurement of Formed Core Samples”, HLW-SSF-TTR-2012-0013 Rev 0, February 23, 2012

3. Miller, D. H., Reigel, M. M., "Task Technical and Quality Assurance Plan for Saturated Hydraulic Conductivity Measurement of Formed Core samples”, SRNL-RP-2012-00133, March 7,2012

4. Cozzi, A. D., Duncan, A. J., "Characterization of Core Sample Collected from the Saltstone Disposal Facility”, SRNL-STI-2009-00804 Rev 0, December 2009

5. $\quad$ Reigel, M. M., Cozzi, A. D. ,Hansen, E. K., Langton, C. A., “Summary of SRNL Curing and Analysis of Saltstone Vault 4 Cell”, SRNL-L3100-2012-00121 Rev 0, August 2012

6. ASTM Method D5084, "Standard Test Method for Measurement of Hydraulic Conductivity of Saturated Porous Materials Using a Flexible Wall Permeameter"

7. Hera, K. R., Hansen, E. K. , "Design and Testing of the Formed- Core Sampling System for the Saltstone Facility Vaults”, SRNL-STI-2010-00167 Rev 0., March 15, 2010

8. Harbour J. R., Williams, V. J., Edwards, T. B., Eibling, R. E., Schumacher, R. F., "Saltstone Variability Study-Measurement of Porosity", WSRC-STI-2007-00352, August 2007 
SRNL-STI-2012-00551

Revision 0

Appendix A. Photographs of Formed Core Samples after Removal from the Vials. 
SRNL-STI-2012-00551

Revision 0
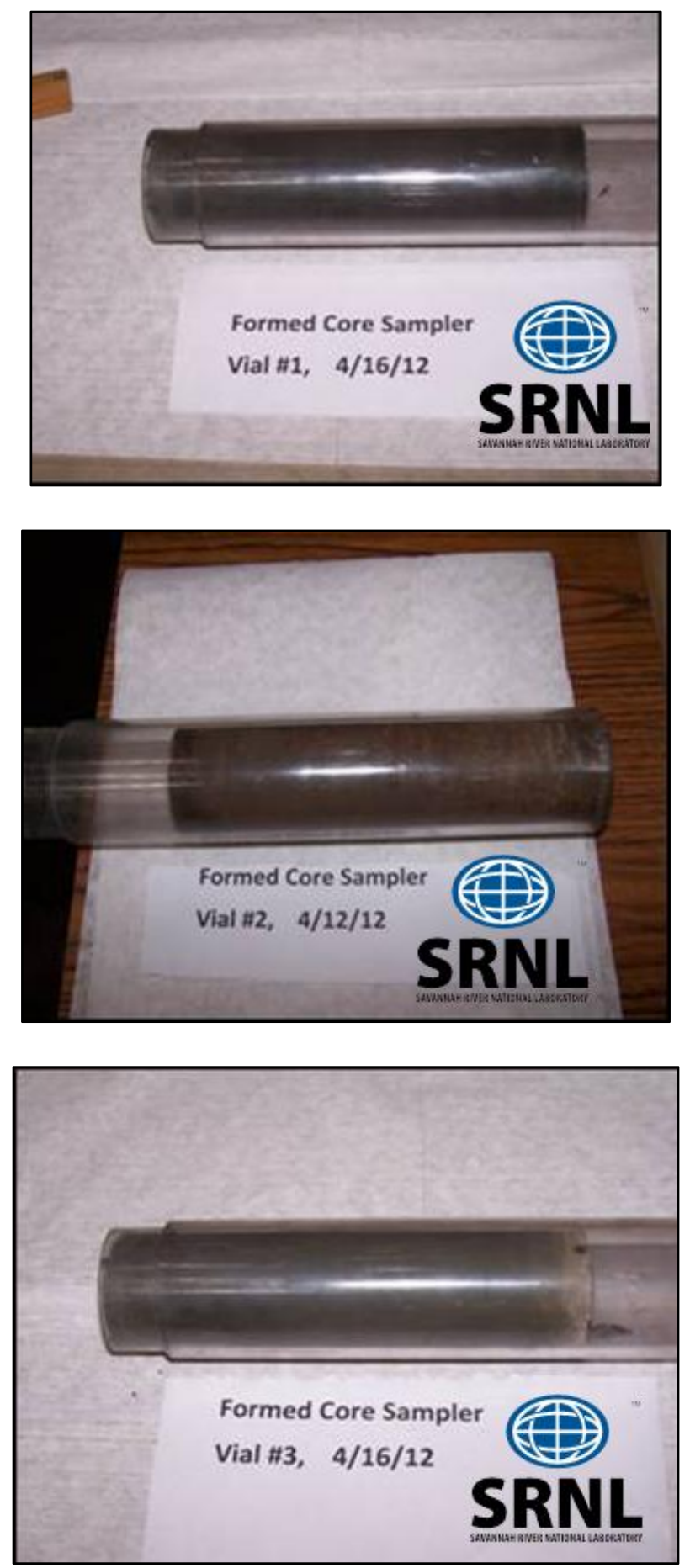
SRNL-STI-2012-00551

Revision 0
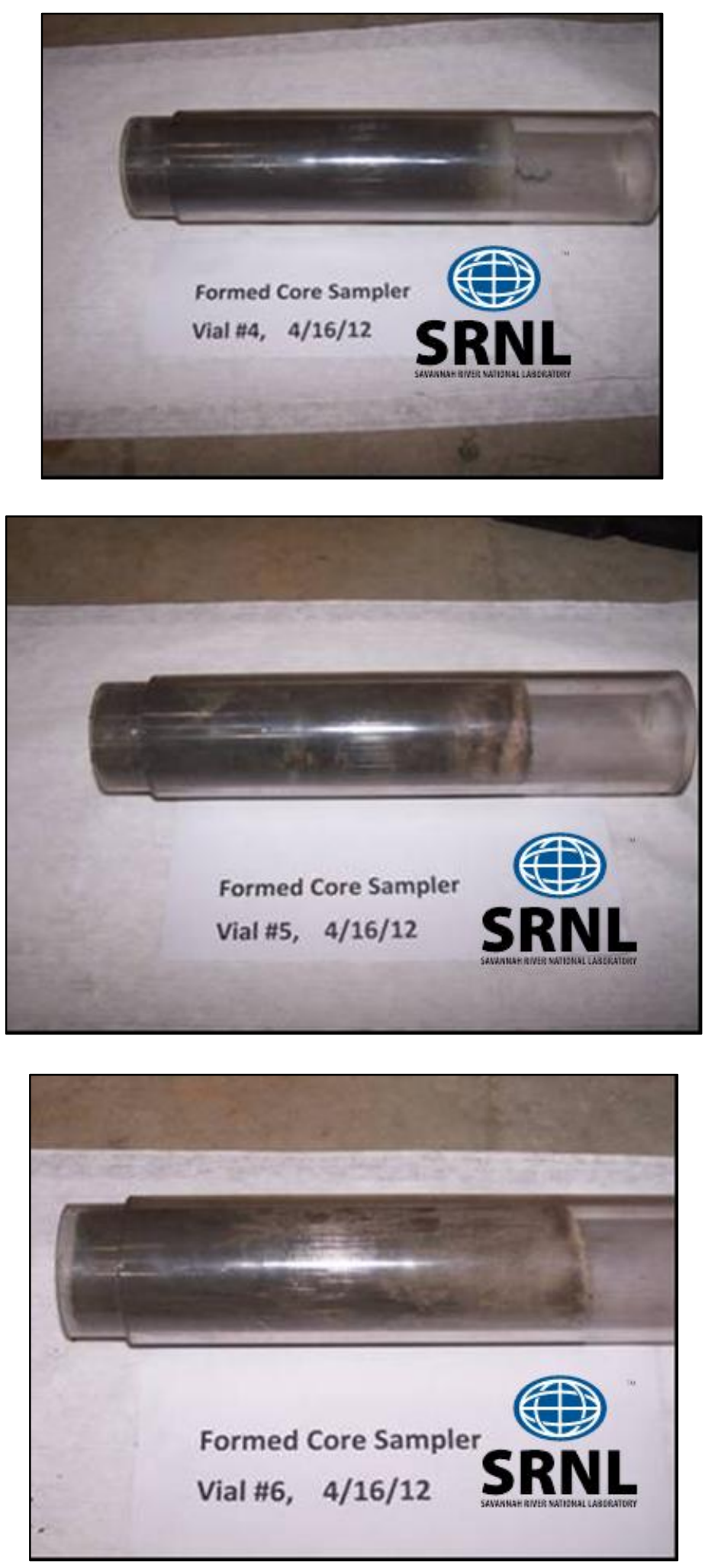


\section{Distribution:}

P. M. Almond

H. H. Burns

T. W. Coffield

A. D. Cozzi

D. A. Crowley

R. E. Eibling

S. D. Fink

K. M. Fox

R. D. Freeman

B. J. Giddings

E. K. Hansen

C. C. Herman

C. A. Langton

P. R. Jackson

S. L. Marra

D. H. Miller

F. M. Pennebaker

B. R. Pickenheim

M. M. Reigel

K. H. Rosenberger

M. G. Serrato

F. M. Smith

D. B. Stefanko

K. H. Subramanian

Records Administration
773-43A

773-41A

705-1C

999-W

773-43A

999-W

773-A

999-W

705-1C

786-5A

999-W

999-W

773-43A

703-46A

773-A

999-W

773-42A

999-W

999-W

705-1C

773-42A

705-1C

773-43A

249-8H

EDWS 